\title{
WORLD MODELS AS ORGANIZATIONAL MODELS: GLOBAL FRAMING AND TRANSNATIONAL ACTIVISM IN THE BRAZILIAN BLACK MOVEMENT
}

\author{
Modelos de mundo como modelos de organização: framing global e ativismo transna- \\ cional no movimento negro brasileiro
}

Alexandre Reis Rosa*

\begin{abstract}
The aim of this article is to explore the appropriation that the Brazilian black movement makes of diasporic content. Throughout history the black diaspora has produced different interpretations of what it means to be black, of what racism is, and produced different ways to fight it. Among these visions is the Black Atlantic, which presents itself as a macrostructure capable of influencing the formation of several frames around the world. The frames are interpretative schemes, world views that serve as a guide for the action of social movements, forming microstructures that represent the diagnoses and prognoses developed during their activities and proposals for struggle, as well as in its organization, forms of action, and resource mobilization. The results show that all these dynamics are related to the alignment of black activism to what is called global framing, which is a process of transnational diffusion formed during local adaptation processes.
\end{abstract}

Keywords: Framing. Race relations. Black movement. Transnational activism.

\section{RESUMO}

O objetivo deste artigo é explorar a apropriação que o movimento negro brasileiro faz dos conteúdos diaspóricos. Ao longo da história a diáspora negra produziu diferentes significados do que é ser negro, do que é o racismo e de como combatê-lo. Entre estas visões está o Atlântico Negro que se apresenta como uma macroestrutura capaz de influenciar a formação de diversos frames ao redor do mundo. Os frames são esquemas interpretativos, visões de mundo que servem de guia para ação dos movimentos sociais, formando microestruturas que representam os diagnósticos e prognósticos desenvolvidos durante suas atividades e propostas de luta, bem como na sua organização, formas de atuação e mobilização de recursos. Os resultados mostram que toda esta dinâmica está relacionada ao alinhamento do ativismo negro ao que se denomina de framing global, que é um processo de difusão transnacional formado durante os processos de adaptação local.

Palavras-chave: Framing. Relações raciais. Movimento negro. Ativismo transnacional.

\footnotetext{
* Professor do Programa de Pós-Graduação em Administração da Universidade Federal do Espírito Santo (PPGAdm/UFES). Doutor em Administração Pública e Governo pela Escola de Administração de Empresas de São Paulo da Fundação Getúlio Vargas (EAESP/FGV). Email: alexandre.r.rosa@ufes.br. ORCID: 0000-0003-06197433
} 


\section{INTRODUCTION}

a

order to understand contemporary social movements one must bear in mind the internal and external aspects that constitute collective action (ZALD; ASH, 1966). In Melucci's words (1989) that means that we should not take such action as presented, nor as being the only thing the movement says about itself. That is, a relationship must be established between the macro and microstructural aspects that influence collective action. An important point that permeates the discussion of social movements is the cultural context that influences collective action (WILLIAMS, 2006). In the case of black movements this context corresponds to the diasporic thinking represented by Pan-Africanist and Négritude movements reinterpreted by the Black Atlantic thesis (GILROY, 2001), which analyses them as a macrostructural dimension responsible for the articulation and diffusion of content across the different regions of the world. That, in the language of multiculturalism, means the various places of exile for Afro-descendants (HALL, 1999).

The Black Atlantic is a metaphor created by the English sociologist Paul Gilroy (2001) to represent the transnational dynamic that characterises black culture. It is a cosmopolitan approach that aims to go beyond the nationalisms that tend to imprison this culture to the "national territory", disconnecting it from its African roots. In this way, the use of the Atlantic Ocean is shown as a way of displacing the representation of this culture from fixed ground (the land) to moving waters (the sea), and with that, to highlight the fluid character that planetary identities can assume nowadays. In this space of representation, the multiple forms of expression of black culture (in music, literature, religion, politics, and organizational forms) that were taken by the black diaspora to the various places of exile that connect geographically to the Atlantic Ocean and culturally to the Black Atlantic.

Part of this content came to life through the civil rights movement and its organizational innovations that, because of their effectiveness, spread within and outside the United States (MORRIS, 1999). They are transmitted by relational mechanisms (interactions and contacts among activists) and non-relational (documents, manifestoes, and shared projects) that contributed to the formation of a global framing that begins to be appropriated by the Brazilian black movement soon after its reorganization, with the founding of the MNU (Unified Black Movement) in 1978. As Guimarães (2003) observes, this diasporic content is incorporated into the repertoire of the black movement, reflected in the proposals for racial classification and public policies based on race. Considering that this content does not have an inherent meaning, as its meaning is developed by the appropriation that is made by the activists, to understand the content it is necessary to access its microstructural dimension, which is determined by the interpretation that is made of such content.

Thus, when the Brazilian black movement interprets this content, it produces its own version of what racism is in Brazil, and of the best way to fight it. This particular version of content generated in a broader context materialises in cultural texts that will have a specific meaning for activists, the groups that are around them, and for those interested in what the movement has to say about the question of race. The thread that runs through these levels of analysis, which goes from the elements that form the cultural text (the Black Atlantic and its diffusion) to the social practice of the Brazilian black movement (interpretation and mediation), is intertextuality. It helps us to understand how world models become 
organization models insofar as the texts produced by the black movement carry elements of other texts produced and diffused transnationally.

With the relationship between text and its context in mind, the objective in this article is to explore the textual dimension of the appropriation that the Brazilian black movement made of the diasporic content in producing its own narrative texts. According to the narrative levels that form the text (PENTLAND, 1999), we have the Black Atlantic as a mechanism which is the generator of a global narrative, that is, macrostructures that provide the elements that influence the tales (accounts) and stories (reports) that are told by and about the black movement, that is, the microstructures that materialise in the narrative texts and represent the diagnoses and prognoses developed by the black movement during its activities and proposals for struggle, as well as in its organization and ways of acting and mobilizing resources. Both are aligned with what is called global framing, which is a process of transnational diffusion generated during the course of local adaptation (TARROW, 2006).

In order to develop these points, the methodology used was the analysis of narratives (RIESSMAN, 1993; NYGREN; BLOM, 2001). Narratives are not only stories about individuals, the social space in which they live, or the society in which they are inserted, but also stories about the intersection of these three elements (LASLETT, 1999). It is these intersections that make narrative analysis a research method that helps us to understand the macro and microdimensions discussed above. The lives narrated cannot be taken as an "element" of the society, because in fact they are the society itself. In fact, the stories about the black movement narrated in this article are based on 38 testimonies granted between 2003 and 2007 by members of the Brazilian black movement for the Oral History program conducted by the Center for Research and Documentation of the Contemporary History of Brazil (CPDOC / FGV-RJ), published in the book compiled by Alberti and Pereira (2007), and also based on the 67 speeches given by activists, intellectuals, and politicians, recorded on shorthand notes at the National Congress, Federal Senate, and Federal Superior Court during the debates on the positive and negative aspects of quota policy and the statute of racial equality carried out between 2007 and 2010.

The article is organized in a narrative structure, and therefore, intertwines stories with theories beginning with a brief historical digression on the trajectory of the Brazilian black movement, highlighting the shifts made in the collective action frames of the movement. It then tells how the process of global framing influenced the pursuit of the internalisation of this content within governments and other actors in civil society. In this process Brazilian activism developed a structure of intra-institutional and party mobilization, which made it possible to construct a diagnosis, prognosis, and resonance aligned with the content spread by black transnationalism within the spheres of power and political decision. In the final part, we discuss how these processes influenced the forms of organization of the Brazilian black movement.

\section{FRAGMENTS OF ORGANIZATIONAL HISTORY AND COLLECTIVE ACTION FRAMES:}

\section{FROM COLONIAL RESISTANCE TO THE CONTEMPORARY BLACK MOVEMENT}

A critical reading of any or all official historiography reveals that the trajectory of many minority social groups tends to be told in an erroneous and/or mean-spirited way 
(CHAKRABARTY, 1992). This seems to be the case with the history of black and indigenous minorities in Brazil. Accounts of the laziness of the Indian and the adaptability and docility of the Negro to slave labour perversely hide the nature of the struggles for equality and justice that characterised, for example, the black resistance throughout the centuries.

In the sixteenth century, the first mass flight of forty slaves in the south of Pernambuco, resulting in the formation of the first quilombos (communities organized by fugitive slaves) and reviving the social organization of the ancient African peoples, represents a milestone in the organized black resistance of Brazil. From then on, a series of other resistance movements would take place, such as the Revolt of the Tailors in 1789; the Malê revolt in 1835; the Balaiada revolt in 1838, among others, with these last revolts having depended on the decisive participation of the black community engaged in the changes in the power structure of Brazilian society (MUNANGA; GOMES, 2006).

According to Fernandes (1989), until the tardy signing of the Lei Áurea ("Golden Law": the law that decreed the end of slavery in the country in 1888), black resistance was engaged in the struggle for the abolition of slavery in Brazil. However, even after 1888, because of the deplorable social conditions of the independently emerging black community, unprepared to compete with white immigrants, the struggle for abolition continued with the understanding that there was a historical debt to the black community. Thus, the common thread of the struggles that have followed has been the collection of this debt motivating other movements of resistance throughout the republic. Among these are: the Revolta da Chibata (Revolt of the Lash) in 1910 (CARVALHO, 1995); the creation of associations, guilds, and clubs for blacks between the years 1910-1920 (DOMINGUES, 2007); the Frente Negra Brasileira (Brazilian Black Front) in 1931 (BARBOSA, 1998); the União dos Homens de Cor (Union of Men of Colour) in 1943 (SILVA, 2003); the Teatro Experimental Negro (Experimental Black Theatre) in 1944 (NASCIMENTO, 2004) and the MNU (Unified Black Movement) in 1978 (COVIN, 2006), which now celebrates its 40 th anniversary and represents the main organization of the black movement, engaged in anti-racist struggle.

When we analyse the trajectory of the black movement throughout the twentieth century (DOMINGUES, 2007), we can observe a maturation of the movement in order to better define its identity and, above all, to take a more radical stance in the face of racism and the miscegenation discourse. During the period from 1978 to 2000, after the creation of the MNU, there were a series of splits with the earlier phases of the black movement, among them: (1) a shift in the political position of the movement from right to Marxist left in 1970 and 1980, in the first stages of the MNU; (2) greater permeability of the movement in relation to international influences, with emphasis on Afrocentrism and the American civil rights movement; (3) the use of the term "afro-descendant" as a self-identification of Brazilian blacks, following the model used in the North American context; (4) the search for the causes of black marginalisation, now as a result of slavery and also of the capitalist system; (5) the search for the solution for racism, now through the educational path and within the framework of a socialist society; (6) the systematic denunciation of the myth of a racial democracy and a radical stance against miscegenation, viewing it as a strategy to dilute black identity; and (7) an increasing proximity to the icons associated with black culture, highlighted by the shift of Black Awareness Day from May 13 to November 20, to honour the date of the death of "Zumbi dos Palmares", one of the pioneers of resistance to slavery. 
In the years that followed, this set of events generated a new profile for the black movement, with new configurations of the frames that guide the action of the movement. In social movement theory, the frames are defined as the basis of an action oriented to sets of meanings and beliefs that inspire and legitimise the campaigns and activities of a social movement. In other words, they are interpretative frameworks that define certain conditions as fair or unfair, assign responsibility for injustice, and point out the alternatives that could be achieved through collective action (SNOW; BENFORD, 1988). In the face of perceived injustices, social movements begin a process of articulation that aims to build alternative mobilization to face some problematic situation or condition that needs to be changed in order to not be unjust. According to Benford and Snow (2000), frames of collective action develop from three functions: diagnosis, prognosis and motivation.

The diagnosis is characterised by the identification of the source, the conditions, or the culprits of the injustice. It is about assigning responsibility to a particular aspect that will be the focus of collective action. The prognosis is characterised by the formulation of one or more proposals to combat the problem diagnosed, as well as tactics and strategies of action that will be used. Thus, there is a close relationship between diagnosis and prognosis insofar as the identification of specific problems tending to restrict the range of possible solutions and strategies that can be used to resolve such injustices. After the prognosis has been defined, the time comes for action and to foster the motivation of the group. This is what Gamson (1995) calls "agency", a process of awareness in which activists believe that it is possible to change a given situation based on the defined prognosis. However, the success of this agency depends on the ability of the movement to "align" the individual and collective spheres around a given prognosis. That is to say, so that the prognosis can cause enough impact to motivate the participation of individuals and the social movement into social action.

Moreover, for a diagnosis and its prognosis to have legitimacy in the social context in which they are being presented, social movements must have resonance. This means that they must reach the public debate so that the proposals have social approval and come to occupy space on the agenda of the decision spheres that can influence and support the movement's action (BENFORD; SNOW, 2000).

For a frame to have such resonance it needs to fulfil some requirements that are fundamental to its acceptance outside the social movement. According to Snow and Benford (1992), these requirements will define the characteristics that the frame may assume, and likewise its resonance, with the requirements being: (1) the coherence of the frames, since they must be logically complementary in their different aspects: tactics, diagnosis, prognosis, set of values and beliefs, etc.; (2) empirical credibility, since they must make sense according to the worldview of that society; (3) the credibility of the promoters of the frame, because its ability to convince that society will depend on who divulges it; (4) experiential commensurability, since the frame must provide the possibility of being tested in the everyday experience of that society; (5) centrality, since they must have values and beliefs essential to the life of the people in that society; and (6) narrative fidelity, since frames must be based on or aligned with the culture of that society, expressed from its narratives, its myths, and its basic assumptions. 
These conditions are not always in place for social movements; conditions that can lead them to develop, elaborate, and diffuse their frames within the society from which they require support. In that sense, the years that followed the political openness to redemocratisation were decisive for the black movement, since they opened many possibilities for the presentation of effective proposals for racial equality policies that converged with the historical demands of the movement. Thus, the solution of racism through politics ("blacks in power!") gained strength in the 1980s and 1990s with the increased proximity of the black movement with political parties (GUIMARÃES, 2001) and, especially in the 1990s, with its movement into the State, participating in its decision-making spheres (SANTOS, 2006).

In that sense, the Zumbi dos Palmares March against Racism, and for Citizenship and Life, held on November 20, 1995, was an important milestone for the black movement and its insertion into the Brazilian State, since it culminated with the creation of a federal agency capable of intervening directly in the formulation of public policies aimed at the black population (SANTOS, 2014). The outcome of the march was the meeting between the then President Fernando Henrique Cardoso and the National Executive Committee for the signing of the decree of November 20, 1995, which established the Interministerial Work Group for the Valorization of the Black Population (GTI), which would be the embryo of the Special Department for the Promotion of Racial Equality (SEPPIR), created years later, in 2003, during the first term of President Lula's administration. After this period of the repositioning of the black movement and, as we shall see below, of its alignment with effective results of collective action, there was a certain consensus building in favour of affirmative action within the contemporary black movement. In large part, the activists understood that this was a valuable tool to end the exclusion of blacks from the labour market and also to combat so-called systemic racism, which tends to reproduce poverty among blacks and their descendants (SANTOS, 2001). Thus, it has become essential to defend quotas and to endorse the statute of racial equality, which are affirmative actions aimed specifically at the black population, whose significance is associated with the Black Atlantic and the principles of racialization that are behind this notion.

\section{FROM GLOBAL FRAMING TO LOCAL ACTIVISM AND INSTITUTIONAL POLITICS:}

\section{THE CONSTRUCTION OF MEANING IN THE COLLECTIVE ACTION OF THE BRAZILIAN BLACK MOVEMENT}

Affirmative action - and its spearhead, quota policy - is the main "remedy" proposed by the Brazilian black movement for the problem of racial inequalities in the country. According to proponents, such an initiative can balance economic asymmetries and enhance black identity at the same time. However, as is to be expected, the prescription of this remedy responds to a diagnosis. In this case, we have a clear diagnosis that blacks are at the margin of power spaces in Brazil, are not represented in their various forums, and still find economic, social, and racial barriers to Social mobility (IPEA, 2011).

To formulate both the diagnosis and the prognosis, the black movement needs to mobilize a set of references and justifications that underpin these positions and make them palpable within the context. It means building a base of support within (motivation) and 
outside (resonance) the movement. Proposals should be consistent with the frame shared by activists within an interpretive scheme that gives meaning to the perceived injustices.

\section{DIAGNOSIS}

The social movements develop diagnoses to identify the factors responsible for the injustice that they intend to fight through collective action. The finding of these factors passes, firstly, through the definition of who suffers these injustices, and then, of the kind of injustice that is suffered. Taking the case of the black movement within this process, we have the development of a diagnosis that aims to identify the identities of the discriminated blacks and the kind of discrimination they suffer. Clearly, there are multiple possibilities in developing a diagnosis that answers these questions, but when it comes to the Brazilian black movement and its connections to the dynamics of the Black Atlantic, this diagnosis has a very particular aspect starting with the very definition of who is black in Brazil.

I work with the notion of being black from three possible benchmarks. Firstly, I consider all African descendants black. All the descendants of Africans are black. A second reference is: who considers themselves as such. You have to be an African descendant, and second, you have to consider yourself black. And a third reference is: who is treated as such. That is, who suffers such discrimination? (ROLAND, 2007, p. 411)

According to the above report, the first reference in defining those who are black is ancestry. That is, the American classification system known as the "One-drop rule" or principle of Hypo-descendence. In this system, every subject born of interethnic relations involving blacks will also be considered black (HOLLINGER, 2003). The second reference requires the subject to recognise himself/herself as black within this system. That can often be a difficult process to face when you are still under the influence of previous racial frames. In some cases, as the following report shows, it will be from the third reference - to be treated as black - that the subject will recognise himself as such.

[...] he suddenly said, "Do you have your mother's photo there?" I said, "Yes, I do". I dug into my wallet, took out a picture of mother and showed him. He looked: "Your mother's white?" I said, "Of course. I'm white, my mother has to be white". He dropped the subject. Then, as soon as he saw that I was totally relaxed, he asked the following: "Is there a picture of your father?" I said, "I don't have one". He said, "Isn't there one?" I said, "There is Friar, I have one, but it's in the bag". "Go get it". I said, "But the bag is already closed and I'm ready to leave". "You're leaving, I want to at least get to know your father by his photo". I open the bag, get the photo of father from deep within, and take it to show him, all humiliated. He says, "Your father is black". I was in complete shock. Immobile, I couldn't move, forwards, backwards, nor downwards. He took a glass of water and said, "What's going on?" I couldn't speak and he said, "Look, you suffer from a serious illness that you're not to be blamed for. You suffer from a very dangerous, contagious disease. It is called "whitening ideology'". (DAVID, 2007, p. 50). 
The narrated episode occurred during the youth of an activist while he was still attending the seminar. Until that occasion, he identified with his mother and saw himself as a white man. That is, as his interlocutor in the story points out, he reproduces the logic of whitening, an ideology that reverses the logic of hypo-descendence. According to Hofbauer (2006), it is biological bleaching aimed at "lightening" the Brazilian population. Thus, instances of racial mixing involving whites, made their descendants "white". Culturally, whitening aimed at assimilating blacks and mestizos, instilling in them the beliefs and values of European white culture. It is, therefore, a principle of Hyper-descendence that, even after Gilberto Freyre's praise for miscegenation, still lasted for a long time, permeating the social imaginary of those who sought to integrate into society.

Friar David's embarrassment in showing his black father's photo also shows us that his being mestizo, the son of an interracial union, puts him ambiguously between two frames with contrary logic that, when imposed, eliminate the possibility of forming an intermediate position, a mestizo identity. It is in this field of ambiguities and possibilities that racial classification systems operate, pushing the mestizo into one of the poles. In the classification proposed by the Brazilian black movement, the mestizo is pushed to the hypo-descendence and then "darkens" in the statistics already naturalised in the form of official discourse. As the speech by the then Minister of the Secretariat for Policies for the Promotion of Racial Equality (SEPPIR) shows:

First of all, I would like to say that, from the point of view of self-declaration, today the national survey by domicile sample points to the Brazilian population declaring itself black, that is to say, black or brown, $50.06 \%$ of the population of our country, which shows what is being discussed as a theme that reaches the majority of the Brazilian population. (SOUZA, 2010)

Thus, the first question of the diagnosis about the identities of the discriminated blacks, is answered with the use of the equation: black + brown = black. It now remains to be seen the kind of discrimination these blacks suffer. In this sense, the black movement sees social indicators with racial boundaries as a valuable tool for an adequate diagnosis.

Denial of information has been one of the most virulent instruments in Brazil, a product of racism and discrimination. A problem about which you have no information doesn't exist. You cannot fight what doesn't exist. If it is not documented, inequality doesn't exist. So we've been struggling for decades for all public information systems in Brazil regarding the population to have this information. Be it in work, education, health, housing, access to credit, to capital $[. .$.$] all these need to have such information. Before, the only place$ where the colour was registered was with the police. The Brazilian State was only interested in proving that blacks are marginal and commit crimes. So we need to have information on the other side of the coin. What are the existing social conditions that lead the black population to a situation of marginality? (ROLAND, 2007, p. 282)

According to the above report, only with the racialization of information systems would it be possible to have a precise dimension of the racial issues in Brazil. With this information, the black movement can make comparisons with the situations of blacks in 
other countries. This helps to further illustrate the asymmetries, not only between whites and blacks in the country, but also among blacks in different countries. Most common comparisons are made between countries such as Brazil, the USA, and South Africa, given the varied forms of racism experienced by these localities and their different strategies to combat it (GUIMARÃES, 1999; SILVA, 2006; SOUZA, 1997). Education is often a subject used in comparisons, since it has been considered by the black movement as the best option in reducing inequalities between blacks and whites. In comparative terms, it can be said that Brazilian blacks were

Unlike North American blacks for example, also victims of slavery, who had their mule and their acre of land, have been subsidised by the state and have been able to create, for example, their schools, their churches, and their universities. When we were slaves here, Cheyney University in Pennsylvania, in the United States of America, founded in 1837, was already receiving its first class of young blacks. Even today in the United States one hundred and seventeen historically black universities carry out this service of including and permitting access to knowledge for blacks in the United States. (VICENTE, 2010)

In addition to the differences in access to higher education that black Americans had, it is important to note that the report also cites that they were able to create their own schools and their own churches, initiatives aligned with W.E.B. DuBois' proposal to create black organizations as a strategy for the conservation of races (DUBOIS, 1897). Not by chance, José Vicente is the rector of the Zumbi dos Palmares Faculty, the only Latin American higher education institution that targets black students. His proposal is inspired by the so-called North-American black colleges, founded in the 19th century to serve black students who were not allowed to study in white universities because of racial segregation (ALLEN; JEWELL, 2002).

Although there have never been legal barriers to the entry of black Brazilians into university, solutions such as these emerge in the Brazilian scenario result from comparisons with the US and the inclusion of blacks through such black institutions. Note that colleges oriented toward the black population are a solution that addresses a specific US problem. However, this does not prevent it from being appropriated by the Brazilian black movement to solve a similar issue, which is the exclusion of blacks in Brazilian higher education, not because of a formal segregation, but because of social and economic mechanisms that have historically placed Brazilian blacks at the margin of this educational level.

\section{PROGNOSIS}

The prognosis consists of one or more solutions that are proposed by social movements to address the injustices identified in the diagnostic stage. For the Brazilian black movement, such proposals revolve around its main "remedy" against the evils of racial exclusion: affirmative action. As discussed earlier, this is one of the few consensuses celebrated by the Black movement and has been its main battle flag. 
The racial issue naturalizes inequality; the racial issue naturalizes the fact that people, by having a certain colour of skin, naturally don't have shelter, it is natural that they beg. That is naturalized in society, and must be changed. The only way we think we can move is through policies that are complementary to universal policies. Complementary policies are policies of the new generation; policies we call affirmative action. (THEODORO, 2010)

There are at least two doors to affirmative action on the agenda of the black movement. The first is through legislature; such as the bill proposed by deputy Abdias do Nascimento after returning from exile in the United States. In the words of Abdias himself

[...] I believe that one of the most important measures of my mandate was to set, in the National Congress, the precedent of a proposal that today is gaining more and more prominence: the institution of specific public policies for the population of African origin, through the so-called Affirmative Action, or Compensatory Action in the language of my Draft Law No. 1,332 of 1983. (NASCIMENTO; NASCIMENTO, 2000, p. 222)

The second door opens by means of a partnership with multinational companies of North American origin that, by requirement of their headquarters, already practice affirmative action with their employees (ALVES; GALEÃO-SILVA, 2004, MYERS, 2003), and contact occurs between these practices and the black movement.

In 1991, when I took over the Coordinating Body of Blacks in the city of São Paulo, news came to me that there was a company in São Paulo that applied affirmative action: Levi Strauss. So one day, I called and said, "I want to meet the director of the company". I got a car and drove to Levi Strauss in the city of Cotia. There, it was mapped out to me the way things happen in the company and I began to realise certain things. Firstly, that it was possible. Secondly, there were some very concrete points. What were they? That affirmative action is not done merely through discussion. Money is needed. The guys had spent almost a million Reais to be able to change because it involved a lot of training, a lot of empowerment, events, support for community projects, anti-racist NGOs [...] (SANTOS, 2007, p. 354)

After this meeting, the affirmative action proposal became palpable by concrete experience. Based on that

I had no doubt: when we adopted it here in Brasilia, the first thing I did was to get the companies together so they could share their experiences. We held a meeting at a Sesc (Social Service of Commerce) building in São Paulo, calling Levi Strauss, Johnson \& Johnson, Motorola, these big companies, all of which I knew had affirmative action policies. I called for a meeting and a seminar. It was really good. There I made a document together with the OIT (International Labour Organization), a very important document. What's the most important thing in this process? I was seeing these companies confirm what I had seen three years ago in 1991. It was possible, right? So I started to work on this topic a little bit within the government, with this directive. (SANTOS, 2007, p. 355) 
Along with quotas, the teaching of African History complements the prognosis of the black movement to promote racial equality. Introduced in the school curriculum of basic education by Law no. 10,639 of 2003 , the proposal aimed to break with the official historiography - which places blacks at the margins of the great national events - and to recognise the contribution of Africans and their descendants in the construction of the country. In addition to being considered a long-standing demand of the black movement, the proposal aligns itself to Afrocentrism insofar as it seeks to displace historical narratives from Europe to Africa (HOSKINS, 1992). This implies deconstructing the European versions of the abolition of slaves and their participation in this process.

\begin{abstract}
Because it's that thing we always say: taking Zumbi out of the cellars of history has already been a tremendous victory, but much is still lacking; there is still that which I call the "kidnapping" of blacks from Africa to Brazil. And there is also much more to be said about how liberation happened. Princess Isabel is still the reference. We brought up Zumbi, but Princess Isabel still exists in schoolbooks, there is still this notion that Blacks did not fight for their emancipation. (BATISTA, 2007, p. 438)
\end{abstract}

Like the proposal of quotas, the teaching of African History has been in operation for some time in the country and therefore occupies a prominent place in the debates on racial inclusion. Other proposals in the areas of education, culture, health, religion, labour market, media, access to housing, access to justice, and sport and leisure are included in the Racial Equality Statute (Law no. 12,288, July 20, 2010), which consolidates the set of proposals that form the prognosis of the Brazilian black movement.

\title{
MOTIVATION AND RESONANCE
}

Once the diagnosis and prognosis have been defined, social movements must convince their activists and motivate them to fight for the cause of the movement. When the Brazilian black movement redefined its platform of struggles after its re-establishment in 1978, it also redefined the frames of collective action that support the diagnosis and prognosis presented. This led to internal disputes between black organizations that did not fully align with this new profile. In addition, one had to consider how this new profile of proposals would be received outside the movement. That is, what would be the resonance of that new black movement?

These two processes share their benchmarks in the form of the founding of the Unified Black Movement (MNU), the intention of which was to align the various organizations with a common platform to form a broader front for racial equality that would be more effective than earlier versions.

The MNU brings a greater level of politicization to racial debates and places the black movement in a more left-wing perspective, which I think was the fundamental influence of all the activism of my generation. I think the most important political fact of the contemporary black movement was that of July 7, 1978, because everything that's happened since is referenced to that 
inaugural act of re-establishment, the contemporary black movement so to speak. Many of the organizations that exist today are reinterpretations of the theses that had existed, because the strategic vision that was put in place at the time is still a guide for today. No other grand thesis ever created was as comprehensive as that which the MNU brought, and it's probably possible to say that it had and has a greater political influence than that of the MNU itself as an institution. In time, the theses ended up surviving longer than the institution itself as originally conceived. (CARNEIRO, 2007, p. 148-149)

The "grand thesis", cited by Sueli Carneiro, is characterized by the alignment of the MNU with the content disseminated by the Black Atlantic. According to Covin (2006), the strategic vision posed by MNU is guided by the principles of pan-Africanism and Afrocentrism. Among them is the preservation of races through racialist thought. The MNU itself, during the Third National Congress held in April 1982, in criticising the myth of a racial democracy and its effects stated: "Many of us believe that "miscegenation" has been a means of preventing racial discrimination and prejudice - as white-black marriages generate "mulattos" and "morenos" (brown-skinned people) - emptying the two extreme poles: blacks and whites", and from that concluding: "[...] for us of the Unified Black Movement, blacks and their descendants constitute a single race and a single people". (MOVIMENTO NEGRO UNIFICADO, 1988, p. 20; 24)

However, in adopting this "grand thesis", the MNU distances itself from the class struggle and places race as an element of autonomous articulation. Although guided by a left-wing perspective, as was common with social movements in the 1970s and 1980s, the MNU could not be considered a classic left-wing movement. In effect, this "left-wing racialism" (RISÉRIO, 2007), coupled with the academic profile of activism, hampered the acceptance of their proposals for a more significant share of activism, with such activism still motivated by other theses.

I didn't feel motivated by the MNU. I found them to be sectarian, within my Marxist vision that I never abandoned - it is interesting, because I deal with the race issue without having abandoned the class paradigm; I never threw away old Marx and company. [...] Another reason why I didn't want to join the MNU is because I dreamt of an entity that was really grassroots, that made illiterate blacks literate, because I had come from an extremely poor family and, besides that, had social commitment installed in me by the church and by the "Partidão" (PCB - Brazilian Communist Party). So it wasn't about racial preaching, so to speak, to an educated audience, because I also understood that as an extremely limited audience. (MOREIRA, 2007, p. 271-272)

If, on the one hand, the link with the base, with the black masses, remains a question mark in the thesis defended by the MNU and the black organizations that came after it, on the other hand, the commitment to the transformation via revolution - typical of the Marxist thesis - was redefined according to that "grand thesis" of the MNU. That is to say, a consensus was gradually built up among the activists that affirmative action would also be a form of revolution. This allowed for a broader adherence, as the following account tells. 
It was a very slow maturation and also very painful, because at various points the question was whether adhering to such a demand would mean an ideological surrender: we, who so loved revolution, would now, let's say, be content with the possibility of sharing the cake without social transformation. Until someone said that we were making an extraordinary social transformation in everyday relations, of the relations of micro-spaces of power, and the very question of the empowerment of the black population, and, the loftiest thing, the most daring in politics, in intersubjective relations. Someone had to say that we were creating the revolution, that quotas in Brazil IS revolution. Now history is showing that it is revolution. There has possibly never been a theme in the Republic that mobilized as much energy as the issue of quotas, either for or against. So we started to think it was cool, it was indeed a revolution. (SILVA Jr., 2007, p. 397)

The level suggested by Edna Roland refers to the diagnosis of blacks in Brazil, which, in turn, refers to the principle of hypo-descendence that guides the model of racial classification proposed by the Brazilian black movement and is currently used by official statistics. The media's interest in Brazil's participation within the Durban conference, as Roland points out, opens up space for the internal articulations of the movement to reach the general public and to allow percentages such as this, $45 \%$, to be introduced into the debate. By placing the race issue at this level and demanding rights through it, the black movement now demands almost half of the "opportunity cake", which invariably alters the logic of competition historically dominated by whites. This causes whites to enter the debate to challenge the prognosis presented.

I think the affirmative action debate has interesting aspects: it brings whiteness out of the closet. Today, there is a reaction from white people to affirmative action in Brazil. Whiteness - as an absolutely articulated, organized, political movement that manages the economy, politics, and communications of that country in tranquillity - showing its hand, so to speak. This ostensibly increases stress in race relations more, because until today that which has gone to the microphone, which has gone to public debate, was blackness - if I were to think of blackness as the antithesis of whiteness. Not now; now whites have been called into the public debate in order to say what they think of race relations. They're being forced to, in fact, because the debate about affirmative action forces the white people to speak up. (SILVA Jr., 2007, p. 470)

Consequently, the black movement succeeds in accomplishing what it always wanted to, since the Brazilian Black Front era in the 1930s, which is to promote a national debate on racial inequalities in Brazil.

Now, it's clear that the quota also provoked a debate, which is: how is black defined in Brazil? What I'm talking about is somewhat intuitive but the view on racism in Brazil is changing. I think that the generation to come already has a different conception, different to the generation of which I was part, which was more about a period of affirmation of the black struggle. We now enter into another stage, which is: what do we mean by being black in Brazil? What do we mean by racism in Brazil and in the world? Because Durban also influenced our generation a lot. (SILVA, 2007, p. 409) 
When whites enter the discussion questioning the proposals of the black movement, especially policies of redistributive character that are the basis of affirmative action policies in the areas of education and health (LIMA, 2010), an important opportunity opens up for detailed diagnoses and prognoses to be discussed, broadening their understanding in the various sectors of society. The risk of this resonance is that while the details are discussed, the defects of the proposal are also discussed, undermining the claims of the movement in the face of arguments against the proposal. In any case, the black movement gains visibility in this process and race relations become part of the national agenda.

\section{GLOBAL FRAMING AND ORGANIZATION: POSSIBILITIES OF BLACK TRANSNATIONALISM}

The directions of collective action described above and their consequences in the development of diagnoses, prognoses, and motivation/resonance, reflect the dynamics of the global framing formed from the connections of the Brazilian black movement with transnational activism. Considering that this frame contributes to the alignment of individual and collective experiences within an interpretative scheme that serves as a guide to action, its consequences can be perceived in the organization of the black movement itself, that is, in its organizational structure, in its strategies of action, and in its mobilization of resources.

\section{STRUCTURE}

Throughout its history, the Brazilian black movement has been characterised by its internal plurality. The organizations that have composed it have managed to converge around certain proposals (for example, affirmative action policies), but within this convergence each followed its own organizational structure in response to the context of the struggles it was experiencing. In fact, we can say that there are different currents within the movement that over time have opted for different forms of struggle, as shown in the following report:

In an attempt to periodize the black movement, I usually say that 1971 begins what we would call the contemporary period of black struggles in Brazil. [...] and later on, in 1978, there is the emergence of the MNU, the Feconezu (Negro Zumbi Community Festival), in São Paulo, and there are other facts besides these that were mentioned. So, there are three divisions: from 1971 to 1978, which I call "the historical turning point;" from 1978 to 1988, which is a phase of organization of the movement, in which new entities arise, have their protests, their accusations [...] In that phase, a split also takes place, involving the party line, the Christian line, and the movement itself, which follows its historical flow and depends neither on parties nor on Christian religious denominations, and identifies itself, in religious terms, with the religiosity of its black African origin. At the same time, there is work, for example, in the Constituent Assembly, which results in the inclusion of blacks in the constitutional text, a result of the movement's work, which sensitised parties or drew from the opportunism of parties. (SILVEIRA, 2007, p. 270). 
The divisions presented by Silveira even help differentiate the segments that make up the black movement, but in practice the boundaries are poorly defined, with overlaps occurring that generate disputes among the lines and within the organizations themselves. In the line he calls "the movement itself", we have several black organizations that follow "its historical flow". Among them is the MNU, the author of the "grand thesis", which at its base deals with internal disputes in defining the profile it will assume.

We made a revolutionary statute. We took the book of Samora Machel, The Struggle Continues, which has the statute of Frelimo, and, based on the Frelimo statute, we made a revolutionary 20-point document. But Hamilton thought that it was bourgeois, very out-dated, Vera Mara supported him, and they were against it. [...] Then they made another [statute]. That came as a recommendation from the organizing committee, but they have already come up with another one. (PEREIRA, 2007, p. 159)

There was a fundamental difference between the two statutes. Why? Our statute said: the MNU has to be a mobilizer. In their statute, it said that the MNU had to be a demand. And this discussion, although it seems a simple thing, is of a theoretical nature; it's a matter of principles. If it is a demand, it does not propose anything, it is only within the scope of making demands. And we said that it would have to mobilize, as we saw that it would have to work within the masses of blacks. Not simply to demand the rights of a black elite - that was what we put forward at the time - but to mobilize the masses of blacks to demand them, because they are underemployed, ghettoized [...] But they didn't have that understanding, didn't want to, didn't agree, they ignored it. This was the argument that really caused the split. (FERREIRA, 2007, p. 160)

In the dispute over the definition of the MNU's statute, the report shows that a non-revolutionary and avant-garde profile prevailed, far from the "masses of black people". On the one hand, it illustrates the origin of the problem being faced, that is, of not being able to be a grassroots organization. On the other hand, it allows a rupture with the horizontal structure of the organizations before the MNU.

The structure of organizations was generally collegial in nature, because people often had difficulty delegating powers. For a long time black organizations refused to have a vertical structure. One might say that this is an inheritance of Catholic political action, because Catholic organizations in general have the collegiate form. But there are also those who say that it was due to difficulties in the delegation of power. This internal work was a task of purging us of the heritage of racism, which is going to manifest itself and manifested itself for a long time. It was manifested in the black organizations themselves, no doubt. The basic idea was that everyone should be on the same level, or that no one could stand out from the group. This would be absolutely normal if people did not coexist with other white organizations, in which the structure was absolutely vertical. (SILVA Jr., 2007, p. 445)

The verticalization of the MNU drew a distinction principally from the line of Christian denomination, but it brought problems of adaptation to the local representations 
of the movement, who had difficulty following the bureaucratic routine demanded by the movement. The following report illustrates the consequences of this organizational structure.

We began to create the MNU groups here and to encourage all those principles and regulations, which eventually became excessive and strangled the MNU in Rio Grande do Sul: those requirements of statute, minutes, reports, frequently impossible to be fulfilled. That was a year, two, three, and four. At first it was a marvel. (MACHADO, 2007, p. 167)

The party line, although seen as separate from others, is formed by the activists linked to the black movement "that follows its historical flow". Therefore, there are overlaps between the party line and the historical line as the activists move between one line and another.

I said, "I'm starting a black movement". She said, "Why don't you come to the PT?" I said, "Party? No". "Edson, why not a party? It is an open party, of the social movements. You can enter the party to get it done. "So, through this invitation from Arlete, and entering into this conversation that it was an open, social movement, I joined the PT (the Worker's Party) to create the PT Black Commission in the Federal District. As I didn't know anyone, I went out looking for people: "Do you know any black activists?" "I know so-and-so". From there we set up the PT Black Commission in August 1984. (CARDOSO, 2007, p. 228)

This capillarisation of the black movement within other institutions allowed the activists to access important spaces of political articulation. In addition, the relationship with the political parties created another important opportunity for black movements, which was appointments to public offices, allowing a voice within the Executive Branch.

I met Ivair, and he and Hélio Santos were setting up the Black Community Council in São Paulo and wanted a unionist to play a role with the central unions. They called me there; I had a job in the union, taught classes to workers, had good traffic within the CUT (a labor Union) in the whole state. In short, I had experience even of the union activism beyond the activism of the black movement. So they proposed that I take that role in the Council. I went to Sao Paulo. (SILVA Jr., 2007, p. 221)

Access to the State allows the black movement to know its functioning structure, its routines, decision processes, and sources of resources that are important to meet part of its demands.

At Sedepron (Extraordinary Secretariat for the Defense and Promotion of Black People, created in 1991) in Rio during the Brizola administration, we didn't manage to make much headway; we were constrained by the State machine. Technical things that bring you down: you think you have great ideas, but these ideas need to be translated into bureaucratic language; you have to have a project, you have to distribute the project budget between the rubrics and so on. [...] And some people have done that work. Ivair is a guy who has 
always been in this junction between the State and civil society, which I think is valid and necessary. You need to have these instances of contact, which, in some way, will lead to the demands of the social movement. They cannot replace the social movement - that's a temptation that one can sometimes be subjected to - but they have a role to play. (MEDEIROS, 2007, p. 351-352)

The common view that social movements behave as challengers, that is, as organizations that must be against the State, preserving its status as an outsider or extra-institutional, has been reviewed in the practice of contemporary social movements. Studies show that there is an increasing permeability between institutionalised and non-institutionalised politics, so that "[...] state institutions and parties are interpenetrated by social movements, often developing outside movements, in response to movements, or in close association with movements". (GOLDSTONE, 2003, p. 2) In the case of the Brazilian black movement

[...] there was great tension, due to the following: any participation in the state was co-optation; you were being co-opted and such. I was clear that it was another political arena in which we were working. But that prevented us, for example, from having a closer relationship with the movement, which was very suspicious of what was going to follow. (SANTOS, 2007, p. 217)

Despite the black movement's distrust of the ramifications within the State, when we observe the action of these activists in the last decades, within the political parties and the State, it would seem that in order to understand the dynamics of the contemporary black movement we must shift our eye attentively to this tendency to view the State as "one more political arena" and away from that common vision of social movements as necessarily extra-institutional organizations.

\section{STRATEGY}

The strategies of action of the Brazilian black movement can be thought of in two phases, according to the structural changes pointed out previously. There is a first phase of greater informality, autonomy, and extra-institutionality, which is marked by street protests, rebellion and hand-to-hand activism. Then, with the entry of the movement into political parties and the State, these strategies take on another form and become more focused on the outcome, with interorganizational alliances and greater use of the political opportunities that arise in these new spaces. The game became more complex and sophisticated, which required bureaucratic skills that few activists possess.

This second phase is called the "racialism of results" by Risério (2007), in which the black movement begins to adopt a more instrumental posture towards the objectives and does not avoid making alliances as long as they allow for greater effectiveness. This strategic perspective contrasts sharply with the first actions taken by the activism.

Sinba (Brazil-Africa Exchange Society) did it this way: we would go to the street and shake it up, go to the suburban sidewalks to sell the Sinba newspaper. We would take brass megaphones with huge speakers. Chagas 
Freitas, trying to urbanise a little, made the great commercial spaces become boardwalks, where traffic couldn't flow. Then they become entirely advertising spaces, places as seedbeds. And there it was great, because we arrived with a paraphernalia of maps, posters with traced letters. For example: we got extracts of the speech against the colonialism by Aimé Césaire, phrases from Luther King; Roberto K-zau made drawings of Angela Davis for us, the Black Panthers, Mahatma Gandhi, Malcolm X. We would put them in the squares, take a preacher and preach from the trees. (PEREIRA, 2007, p. 197-198)

It was a kind of hand-to-hand mobilization, with the advantage of being very close to people, but with the disadvantage of having very little scope. Not to mention the risk of clashes with the police or groups opposed to the proposals presented in the "brass megaphones". This was also accomplished through cultural actions, which sought to mobilize black youth around African music and traditions.

This form of mobilization has been seen by the black movement and by some analysts as a cultural practice that, because it is not a political practice, contributes little to the anti-racist struggle. For Hanchard (2001), practices like this were responsible for the low effectiveness of the Brazilian black movement in breaking with the white hegemony, which was based on the myth of racial democracy, the dynamics of which were the main reason for the invisibility of racism. For the author, the black movement was trapped in a kind of "culturalism" that prevented the politicization of the theme and the formulation of more effective public inclusion policies.

Among the cultural and political dimensions were the actions of the black movement in the field of education. With an approach distanced from the street, but still hand-to-hand, some activists sought black awareness in school, working on black self-esteem and recognition of the contribution of blacks to the history of Brazil. As the following account tells us:

And then we started to adopt a practice. Before beginning lectures, we would ask, "Who here is black?" No one. "Ah, no blacks?" Then, in the end, after we had shown the whole story of the Negro, we would ask: "And now let's see: who here is black?" Everyone raised a hand. And so we were learning from that. We weren't on the periphery, on the inside, just to teach, it was an apprenticeship. And with my camera, I started taking pictures of those also on the periphery. Later I would return with those photos and my slide projector, I would roll out a sheet in the middle of the street, and they got used to seeing each other. (ARAÚJO, 2007, p. 205)

Looking now at the black movement solely in the political arena, but still with hand-to-hand and partly extra-institutional actions, the marches appear as a very fruitful strategy of action, judging by the results obtained with the March against the Abolition Scam in 1988, and the Zumbi dos Palmares March in 1995. In both cases, it was possible to mobilize a large number of activists and also attract the attention of the mainstream media to the protests that aimed, above all, to denounce racism in Brazil.

However, as we have already pointed out, when we look at the March of 1995 and the result achieved by it with the creation of the GTI (Ministerial Working Group, which eight years later would become SEPPIR, or Secretariat of Politics of Promotion of Racial Equality), 
we have in fact a mixed strategy, involving extra and intra-institutional actions. That is, on the one hand there was the link-up between the black organizations and the unions so that there was the largest possible number of people in the march; on the other, there were the links made inside the State so that President Fernando Henrique Cardoso (FHC) would welcome the march and sign the commitment with the GTI.

We coordinated well in Brasilia with the support of the government of Cristovam Buarque, who was the governor. It was a period when I was doing that kind of thing: traveling, talking to people, going to São Luís, saying that the march was real ... Because when it's time to mobilize a black movement you don't know what ghosts will appear. So it's not easy to do such a thing. What was the advantage we had in 1995? In government was Fernando Henrique Cardoso, and then PT and CUT made their assessment that the march might be interesting. Yet, at the same time, they were not accepting of a black claims agenda or the autonomy of the black movement. They were keeping an eye on the opposition to Fernando Henrique. Already there were rumours of people who were going to shout "FHC Out!" at the March - 1995, which was the first year of Fernando Henrique [as president of Brazil]. (CARDOSO, 2007, p. 338-339)

If the march had not counted on the links made within the State, probably those "ghosts that appear" could have harmed the creation of the GTI. In that sense, when the black movement assumes the state as "one more political arena", it understands that often - as in the case of the creation of the GTI - extra-institutional action alone may not be the best way to go. This understanding comes to the black movement from the first experiences within the State of São Paulo, still at the time of the Montoro government, when the creation of the Black Community Participation and Development Council was formed in 1984.

Right from the very beginning of the government there was great dissatisfaction, because there was no effective participation of blacks within the government; very few people had managed to be named in the government. But two people were in the Palace: myself, who worked on political issues, and Hélio Santos, who worked in the Montoro ceremonial. But I could see, for example, that the women had set up a council, the Council for Women's Affairs. From that experience I suggested to the Secretary of Political Affairs, to the chief of staff Carlos Figueiredo: "Why not create a black council?" He found the idea interesting and gave me the green light. I started working on it. I talked to Helio, who found it interesting, and talked with other colleagues: Antônio Carlos Arruda and Genésio. And the four of us started working on this idea politically. [...] but between the decision to create the Council and it actually being created, that involved a process, because people saw the creation of a governing body of blacks as a body that would contribute to racism. At that time the Afonso Arinos Law (First Brazilian Law, created in 1951, to include among criminal contraventions the practice of acts resulting from race prejudice) was still in force. So the whole task was to convince others that that body was going to use politics to fight racism. And since we worked in government, one soon learned one thing: that it was important to guide the actions of the movement within the governmental agenda, the political agenda of the country. We started working with that outlook. (SANTOS, 2007, p.215-216) 
On another occasion, during a world conference against racism in Durban, proximity to the representatives of the Brazilian government enabled access that the black movement would seldom have if its memers did not have transit within the State. As Edna Roland, who was appointed rapporteur for the conference, recalls:

When I thought I had a suggestion to make, I would put it in his ear, write it down: "Ambassador, say so and so, do this". I had to offer tools so he could intervene in the debate. And he even asked me, at a certain moment, to negotiate for Brazil, to participate in some groups that were negotiating texts or concepts. (ROLAND, 2007, p. 381)

In all experiences of intra-institutional activism, we can note that some aspects are fundamental to the success of activism in this political arena: (1) attention to the spaces in the governmental agenda; (2) anticipation of events involving government decisions; (3) proximity to decision makers; and (4) ability to have a dialogue with different political profiles. Although they contain the imminent risk of being co-opted or of not precisely meeting the demand of the black movement, we cannot fail to recognise the results obtained by what I term here as intra-institutional activism. This insertion of the black movement into the political system is a benchmark of the antiracist struggle in Brazil and may be one of the factors that differentiate it from other movements of this kind in other countries.

\section{MOBILIZATION OF RESOURCES}

The approach to the mobilization of resources helps us understand how social movement organizations (SMO) acquire resources to develop their activities and to achieve their goals. To this end, "[...] each SMO must have resources, including legitimacy, money, facilities and labour, which are controlled by individuals and other organizations" (MCCARTHY; ZALD, 1977, p. 1220). In this sense, similar to what occurs with structure and strategy, the mobilization of resources in the Brazilian black movement can also be considered through two phases.

Funding of the black movement has also expanded in recent decades with the black NGO boom, notably in the 1980s and 1990s, seeing funding coming mainly from the public budget and from international cooperation (HERINGER, 2001). However, to reach this stage, the movement had to nurture the idea of external financing within activism. The first such financing, as early as the 1970s, occurs in an unplanned manner and with strong resistance on the part of some activists.

In 1977, an American named Jimmy Lee, who had come to Brazil to play basketball for Flamengo, proposed to obtain funds from the Interamerican Foundation for the purchase of a headquarters. This appeal would become a grant, because Interamerican was from the US Congress and would lend money for the purchase of a house. And Benedito Sérgio bought his headquarters at 208 Mem de Sá Avenue, and there he installed the IPCN (Research Institute in Black Culture). [...] and it was distressing for Benedito Sérgio to buy his headquarters, because people were against it, they thought that the 
money was from the $\mathrm{CIA}$, which was kind of dangerous [...] I was one of those myself. (FERREIRA, 2007, p. 145-146)

Due to the Cold War and the political moment that the country was experiencing in the 1960s and 1970s, there was much distrust of social movements in relation to government actions (GOHN, 1995). Especially in the United States, which supported military regimes in Latin America. With the beginning of political openness, during the Geisel government, the suspicions diminished and some black organizations began to see an important ally in international cooperation.

So the seed began to emerge, the idea of building the Ceap (Center for the Articulation of Marginalized Populations). In fact, it is work that has been going on since 1979, that represents more than 25 years of work, although as a formal institution, Ceap was created in 1989. It would be the first black $\mathrm{NGO}$, in fact, with NGO characteristics. And it started that controversy in the black movement: "international money!" All that confusion, mistrust I would even say. Today everyone is 'on the boat', but at that time we got a lot of stick because there was a lot of mistrust. [...] The CUT and everyone else was born out of these types of resources that were linked to so-called international cooperation, which had an agenda for the democratisation of the country and human rights issues - that's what we entered into. This was a conversation with Rubinho, who was a friend of mine, an anthropologist who works with the indigenous people of the National Museum, who ended up introducing me to this area of international cooperation, which had already helped the Alumni Association - such was its framework. (SANTOS, 2007, p. 288-289)

Even with openness to external financing, and putting everyone "on the boat", this has not eliminated controversies surrounding international cooperation, especially in the field of race relations where suspicions remain of the manipulation of international agencies in regard to the parameters of racial classification in Brazil. To refute the accusations against American foundations, Telles (2002, p.145) addresses the case of the Ford Foundation, which "[is] the largest financial supporter of black movement organizations in Brazil and the largest philanthropic supporter of research on race relations". The author argues that the foundation does not impose racial models on the projects it finances, but that these projects aim to, in part, "[...] strengthen black leadership, sponsoring training such as in public administration courses, campaign elections, and the English language" and that the Human Rights program may "[...] provide important lessons for Brazilian peers". (TELLES, 2002, p. 151, my emphasis) That is to say, if the Ford Foundation cannot be accused of disseminating models of racial classification or anti-racist struggle, we can say that it is able to exert great influence in that process.

Thus, contributing to the formation of activists, exchanges between international organizations, and with the legal lessons of the American anti-racist struggle, the Ford Foundation broadens the channels of dialogue between the black movement and international cooperation, as all this accumulated background translates into new fundraising projects, which are developed according to the expectations of these foundations, whose rationale is restricted. In this sense, black women's organizations stand out the most. 
The following year, I think it was 1990 already, Ford's financing of SOS Racism came along. It was the first major funding. The Coalition was small, for that excursion, but along came Ford, which was big funding. At the same time, Carmem Barroso, who was from the Carlos Chagas Foundation in Brazil and had gone to the United States to run a Population Program, came to Brazil and was looking for interesting projects and institutions to finance. She had been my scientific methodology teacher at USP (University of Sao Paulo) when I studied social sciences. I sought out Carmem to say that we were with this black women's organization, and ask whether the MacArthur Foundation could support us. She showed interest and asked us to come up with a project. The MacArthur Foundation supplied the second major funding. Ford financed the Geledés Human Rights Program and the MacArthur Foundation, the health program. (ROLAND, 2007, p. 283-284)

This support is not only restricted to US foundations, but also includes multinational corporations and the Brazilian government.

We have had institutional support from the Ford Foundation since 1991, 1992. I think our first funding was from an international organization that deals with the area of health, the Coalition. Historically we were, or have been, supported by the Coalition, the Ford Foundation, and the MacArthur Foundation, and we have also had some projects with the Ministry of Justice - because we have a human rights program that is quite vast - the Palmares Cultural Foundation, the Levi Strauss Foundation, Kodak of Brazil, Xerox, and the Bank of Boston Foundation - these are more recent. (CARNEIRO, 2007, p. 280)

It is important to emphasise that even in the light of this financing channel being opened by international cooperation, many black organizations still face the same difficulties identified by Fernandes (1965) in the 1960s, which is the lack of political support and financial resources. Many of them survive from donations or their own resources. When we talk about resource mobilization within the Brazilian black movement, we have to consider the existence of these two realities. This also applies to the structure and strategy of the movement. Thus, borrowing the two profiles coined by Risério (2007) and the three questions analysed in this section, we can define the organization of the black movement according to Table 1.

Therefore, we have two organizational profiles that coexist in the Brazilian black movement. One of them more aligned with the early moments of the black movement in which a left orientation prevailed, with more horizontal structures and street protest strategies focused more on the relationship with the community and on person-to-person contact for racial awareness. The other profile is more structured, with strategies of political articulation within the power spheres of political parties and the State, with more financial resources and a planned pursuit of results. Both recognize blackness as the fruit of an African ancestry, which cultivates the values of the black race and, therefore, seeks to preserve it by rejecting the existence of the mestizos.

Although the left-wing racialism profile still guides the functioning of some black organizations, it gradually gives way to the more structured profile of racialism of results. As 
the latter gains more ground, black participation in the various sectors of society, especially in political parties (now with an eye to the black vote) and in the State that begin to create and/or to mature secretariats and ministries directed towards the racial cause. This also increases the chances of a more active activism in these areas of decision and power.

Table 1 - Organizational profiles of the Brazilian black movement

\begin{tabular}{|c|c|c|}
\hline Profile Aspects & Left-wing Racialism & Racialism of Results \\
\hline General Guidance & $\begin{array}{l}\text { Radical change in society, left political align- } \\
\text { ment and rupture with the capitalist system }\end{array}$ & $\begin{array}{l}\text { Incremental changes in society, center-left } \\
\text { political alignment and maintenance of the } \\
\text { capitalism system }\end{array}$ \\
\hline Structure & $\begin{array}{c}\text { Collegial decision-making, with a low degree } \\
\text { of verticality and lacking orientation towards } \\
\text { the achievement of results }\end{array}$ & $\begin{array}{l}\text { Centralized decision-making, high degree } \\
\text { of verticalization and very oriented towards } \\
\text { the achievement of results }\end{array}$ \\
\hline Strategy & $\begin{array}{l}\text { Street protests, marches, distribution of } \\
\text { pamphlets, and school awareness }\end{array}$ & $\begin{array}{c}\text { Marches, awareness in the media, a } \\
\text { political voice }\end{array}$ \\
\hline $\begin{array}{l}\text { Resource } \\
\text { Mobilization }\end{array}$ & Donations, government, and own resources & $\begin{array}{l}\text { Donations, business, government, and } \\
\text { international cooperation }\end{array}$ \\
\hline Area of Operation & $\begin{array}{c}\text { Closer to the community, with local, regional, } \\
\text { and national scope, and extra-institutional } \\
\text { movement }\end{array}$ & $\begin{array}{c}\text { Closer to elites, with regional, national, and } \\
\text { international scope, and intra-institutional } \\
\text { movement }\end{array}$ \\
\hline
\end{tabular}

Source: Developed by the author.

\section{FINAL CONSIDERATIONS}

The dynamics of the Black Atlantic leads us to think of the black movements of the post-colonial countries connected to the Atlantic as a mere reflection of global struggles against racism. In particular, those that occur in the U.S., because as Gilroy himself says (2001, p.23), "[...] black people everywhere are increasingly encouraged to accept and internalise North American interpretations of blackness that circulate through corporate agents called to develop remote markets for African-American 'software'".

However, unlike the more common interpretations that speak of a mimetic Brazilian black movement, which tends to copy the civil rights movement in its practices of mobilization and action, we note that this is not entirely true. We may even acknowledge that there are points of convergence, but there are also points of divergence that make the antiracist struggle in Brazil such a unique experience. Through diagnosis and prognosis, they approach them insofar as they work within the racialist perspective and understand that the best "remedy" for dealing with inequalities is the adoption of affirmative action, with quotas as the spearhead of these actions. However, when we compare motivation, resonance, and especially organization, we observe a divergence.

In the US, the anti-racist struggle established itself from a grassroots movement, involving several black communities in different social and religious segments, with mostly extra-institutional forms of action. In Brazil this struggle takes another form, as it leans towards a vanguard struggle, articulated by black organizations with low adherence in communities and mostly by means of intra-institutional forms of action. 
It can be observed that the greatest advances of the Brazilian black movement were based on the racialism of results, which ideologically aligned with transnational activism, but developed its own form of organization with party and bureaucratic alliances, which made it more politicised and less culturalist. Paradoxically, this change comes close to Hanchard's (2001) prognosis, when he defends a political stance in the place of culturalism, but at the same time distances itself when the same author warns of the need for the black movement to become less diasporic and more parochial. Indeed, if the movement does not confront problems in the organizational field, it may be in the ideological field that it will have its greatest impact, since parochialism will be its greatest obstacle during the process of local adaptation.

Although the Brazilian black movement has superseded the discourse of "racial democracy", it is still present in several segments of society. Although many analysts attribute this phenomenon to an alleged exceptionality of the Brazilian case, Sansone (1996) shows that the phenomenon of miscegenation is present in countries like Venezuela and Colombia where the "mestizo" is called cafe con leche (coffee with milk), in Puerto Rico trigueño (brown), in Santo Domingo indio quemado (burned Indian) and in Haiti prietos (dark-skinned). Thus, we can say that in the scope of Brazilian society the processes of local adaptation of the racialist frame can find difficulties when confronting a type of non-racialist frame aligned to the idea of miscegenation. In fact, an emerging issue to be investigated would be to analyse this same phenomenon in other Black Atlantic countries, such as African, Latin American, and Caribbean countries, which could reveal interesting dimensions of struggle and organization to better understand our own anti-racist struggle.

In the very cradle of the racialist frame, the USA, this idea of miscegenation has been slowly developing since the 1970s, when there was an increase in the number of interracial marriages and the consequent increase in the number of mixed race children. This new segment begins to question the binary classification system (SPICKARD, 1992) and to claim the right to freely choose one's ethnic identity without being constrained by the criterion of hypodescence represented by the one-drop rule (ROCKQUEMORE; AREND, 2002). This has generated multiracial collective actions that have been organized in the last three decades to modify the information of the American census and include the mestizo population as an autonomous category, unrelated to the old black/white binary classification system (SPENCER, 1997). The actions of organizations such as the Association of MultiEthnic Americans (AMEA) have been pressing the US government to make changes in this direction. However, these organizations have faced resistance from blacks, who see this as harmful because it divides the "black community" into smaller and weaker ones. On the part of whites, there is a resistance to change the status quo of the one drop-rule, created by whites themselves to keep blacks and their descendants in subalternity (LEE; BEAN, 2004). What strikes us in this dynamic is that while the Brazilian government has been pressured to create a system of bipolar racial classification similar to the one in the US, the latter, in turn, have been pressured to create a system similar to ours. A comparative Brazil-US analysis could reveal why this reverse movement occurs and how this dynamic will be put into circulation in the Black Atlantic.

Finally, a provocative theme that has been on the margins of our analysis - and has in fact sidelined most studies dealing with race relations - is the so-called anti-racism without race. As Gilroy (2000) argues, race can be a "toxic" concept that contaminates 
and weakens society as a whole. Thinking of the world in terms of races, whether for good or bad, does not improve our perception of human differences at all, since it supports a colonial construct designed to imprison certain groups in a subordinate position. At a time when genetics has proven that there are no significant differences between humans from the biological point of view, and there are increasing numbers of those of mixed race, fruits of centuries of interethnic miscegenation, attributing a human classification based on phenotype or ancestry has become difficult to sustain. This puts forward, therefore, the challenge of thinking about social relations as phenomena mediated by culture and not by skin colour or the physical traits that people bring with their bodies. Even if these bodies are malleable to the point of being able to be transformed. Models of alternative worlds may perhaps inspire the next organizational models of the twenty-first century.

\section{REFERENCES}

ALBERTI, V.; PEREIRA, A. (orgs.). Histórias do movimento negro no Brasil: depoimentos ao CPDOC. Rio de Janeiro: FGV, 2007.

ALLEN, W.; JEWELL, J. A backward glance forward: Past, present and future perspectives on historically Black colleges and universities. The Review of Higher Education, v.25, n.3, p.241-261, 2002.

ALVES, M. A.; GALEÃO-SILVA, L. A crítica da gestão da diversidade nas organizações. Revista de Administração de Empresas, v.44, n.3, p.20-29, 2004.

ARAÚJO, M. Entrevista concedida ao Programa de História Oral do CPDOC. In: ALBERTI, V.; PEREIRA, A. (orgs.). Histórias do movimento negro no Brasil: depoimentos ao CPDOC. Rio de Janeiro: FGV, 2007.

BARBOSA, M. (org.). Frente Negra Brasileira: Depoimentos. São Paulo: Quilombhoje, 1998.

BATISTA, J. Entrevista concedida ao Programa de História Oral do CPDOC. In: ALBERTI, V.; PEREIRA, A. (orgs.). Histórias do movimento negro no Brasil: depoimentos ao CPDOC. Rio de Janeiro: FGV, 2007.

BENFORD, R.; SNOW, D. Framing processes and social movements: an overview and assessment. Annual Review of Sociology, v.26, p.611-639, 2000.

CARDOSO, E. Entrevista concedida ao Programa de História Oral do CPDOC. In: ALBERTI, V.; PEREIRA, A. (orgs.). Histórias do movimento negro no Brasil: depoimentos ao CPDOC. Rio de Janeiro: FGV, 2007.

CARNEIRO, S. Entrevista concedida ao Programa de História Oral do CPDOC. In: ALBERTI, V.; PEREIRA, A. (orgs.). Histórias do movimento negro no Brasil: depoimentos ao CPDOC. Rio de Janeiro: FGV, 2007.

CARVALHO, J. M. Os bordados de João Cândido. História, Ciências, Saúde - Manguinhos, v.2, n.2, p.68-84, 1995.

CHAKRABARTY, D. Postcoloniality and the artifice of history: who speaks for "Indian" pasts? Representations, v.37, p.1-26, 1992. 
COVIN, D. The Unified Black Movement in Brazil, 1978-2002. North Carolina: McFarland \& Company, 2006.

DAVID, F. Entrevista concedida ao Programa de História Oral do CPDOC. In: ALBERTI, V.; PEREIRA, A. (orgs.). Histórias do movimento negro no Brasil: depoimentos ao CPDOC. Rio de Janeiro: FGV, 2007.

DOMINGUES, P. Movimento negro brasileiro: alguns apontamentos históricos. Tempo, v. 12, n.23, p.100-122, 2007.

DUBOIS, W. E. B. The conservation of races. American Negro Academy Occasional Papers, n. 2, Pennsylvania State University, p.1-14, 1897.

FERNANDES, F. A integração do negro na sociedade de classes. São Paulo: Nacional, 1965.

Significado do Protesto Negro. São Paulo: Cortez, 1989.

FERREIRA, Y. Entrevista concedida ao Programa de História Oral do CPDOC. In: ALBERTI, V.; PEREIRA, A. (orgs.). Histórias do movimento negro no Brasil: depoimentos ao CPDOC. Rio de Janeiro: FGV, 2007.

GAMSON, W. Constructing social protest. In: JOHNSON, H.; KLANDERMANS, B. (Eds.) Social movements and culture. Minneapolis: Minnesota Press, 1995.

GILROY, P. Against race: imagining political culture beyond the color line. Cambridge: Harvard University Press, 2000.

. O Atlântico Negro: Modernidade e dupla consciência. São Paulo/Rio de Janeiro: Ed. 34/UCAM, 2001.

GOHN, M. História dos Movimentos e Lutas Sociais. São Paulo: Loyola, 1995.

GOLDSTONE, J. Introduction: bridging institutionalized and nonintitutionalized politics. In: . (ed.) States, parties and social movements. London: Cambridge University Press, 2003.

GUIMARÃES, A. S. Combatendo o racismo: Brasil, África do Sul e Estados Unidos. Revista Brasileira de Ciências Sociais, v.14, n.39, p.103-115, 1999.

. A questão racial na política brasileira (os últimos quinze anos). Tempo Social, v. 13, n.2, p.121-142, 2001.

. Como trabalhar com "raça" em sociologia. Educação e Pesquisa, v. 29, n. 1, p. 93-107, 2003.

HALL, S. Thinking the Diaspora: home-thoughts from abroad. Small Axe, v.6, n.1, p.1-18, 1999.

HANCHARD, M. Orfeu e o Poder: O Movimento Negro no Rio de Janeiro e São Paulo (19451988). Rio de Janeiro: Eduerj, 2001.

HERINGER, R. Mapeamento de ações e discursos de combate às desigualdades raciais no Brasil. Estudos Afro-Asiáticos, v. 23, n. 2, p.1-43, 2001.

HOFBAUER, A. História de branqueamento ou o negro em questão. São Paulo: Unesp, 2006. 
HOLLINGER, D. Amalgamation and hypodescent: the question of ethnoracial mixture in the history of the United States. The American Historical Review, v. 108, n. 5, p. 1363-1390, 2003.

HOSKINS, L. Eurocentrism vs. Afrocentrism: a geopolitical linkage analysis. Journal of Black Studies, v. 23, n. 2, p. 247-257, 1992.

INSTITUTO DE PESQUISA ECONÔMICA APLICADA (IPEA). Retrato das desigualdades de gênero e raça. 4. ed. Brasília: Ipea, 2011.

LASLETT, B. Personal narratives as sociology: featured assay. Contemporary Sociology, v. 28, n. 4, p. 391-401, 1999.

LEE, J.; BEAN, F. America's changing color lines: immigration, race/ethnicity, and multiracial identification. Annual Review of Sociology, v. 30, p. 221-242, 2004.

LIMA, M. Desigualdades raciais e políticas públicas: ações afirmativas no governo Lula. Novos Estudos CEBRAP, n. 87, p. 77-95, 2010.

MACHADO, H. Entrevista concedida ao Programa de História Oral do CPDOC. In: ALBERTI, V.; PEREIRA, A. (orgs.). Histórias do movimento negro no Brasil: depoimentos ao CPDOC. Rio de Janeiro: FGV, 2007.

MCCARTHY, J.; ZALD, M. Resource mobilization and social movements: a partial theory. American Journal of Sociology, v. 82, p. 1212-1241, 1977.

MEDEIROS, C. A. Entrevista concedida ao Programa de História Oral do CPDOC. In: ALBERTI, V.; PEREIRA, A. (orgs.). Histórias do movimento negro no Brasil: depoimentos ao CPDOC. Rio de Janeiro: FGV, 2007.

MELUCCI, A. Um objetivo para os movimentos sociais? Lua Nova, v. 17, n. 1, p.49-66, 1989.

MOREIRA, D. Entrevista concedida ao Programa de História Oral do CPDOC. In: ALBERTI, V.; PEREIRA, A. (orgs.). Histórias do movimento negro no Brasil: depoimentos ao CPDOC. Rio de Janeiro: FGV, 2007.

MORRIS, A. A retrospective on the Civil Rights Movement: political and intellectual landmarks. Annual Review of Sociology, v. 25, p. 517-539, 1999.

MOVIMENTO NEGRO UNIFICADO (MNU). 1978-1978 - 10 anos de luta contra o racismo. São Paulo: Confraria do Livro, 1988.

MUNANGA, K.; GOMES, N. O Negro no Brasil de Hoje. São Paulo: Global, 2006.

MYERS, A. O valor da diversidade racial nas empresas. Estudos Afro-Asiáticos, v. 25, n. 3, p. 483-515, 2003.

NASCIMENTO, A. Teatro Experimental do Negro: trajetória e reflexões. Estudos Avançados, v. 18, n. 50 , p. 209-224, 2004.

NASCIMENTO, A.; NASCIMENTO, E. Reflexões sobre o movimento negro no Brasil, 19381997. In: GUIMARÃES, A.; HUNTLEY, L. (orgs.). Tirando a Máscara: ensaios sobre racismo no Brasil. São Paulo: Paz e Terra, 2000. 
NYGREN, L.; BLOM, B. Analysis of short reflective narratives: a method for the study of knowledge in social workers actions. Qualitative Research, v. 1, n. 3, p. 369-384, 2001.

PENTLAND, B. Building process theory with narrative: from description to explanation. Academy of Management Review, v. 24, n. 4, p. 711-724, 1999.

PEREIRA, A. Entrevista concedida ao Programa de História Oral do CPDOC. In: ALBERTI, V.; PEREIRA, A. (orgs.). Histórias do movimento negro no Brasil: depoimentos ao CPDOC. Rio de Janeiro: FGV, 2007.

RIESSMAN, C. Narrative analysis. London: Sage, 1993.

RISÉRIO, A. A utopia brasileira e os movimentos negros. São Paulo: Ed. 34, 2007.

ROCKQUEMORE, K.; AREND, P. Opting for white: choice, fluidity, and black identity construction in post-civil rights America. Race and Society, v.5, n.1, p.49- 64, 2002.

ROLAND, E. Entrevista concedida ao Programa de História Oral do CPDOC. In: ALBERTI, V.; PEREIRA, A. (orgs.). Histórias do movimento negro no Brasil: depoimentos ao CPDOC. Rio de Janeiro: FGV, 2007.

SANSONE, L. Nem somente preto ou negro: o sistema de classificação racial no Brasil que muda. Afro-Ásia, v. 18, n. 2, p. 165-187, 1996.

SANTOS, H. A Busca de um Caminho para o Brasil. São Paulo: Senac, 2001.

SANTOS, I. O Movimento Negro e o Estado (1983-1987). São Paulo: Imprensa Oficial, 2006.

. Entrevista concedida ao Programa de História Oral do CPDOC. In: ALBERTI, V.; PEREIRA, A. (orgs.). Histórias do movimento negro no Brasil: depoimentos ao CPDOC. Rio de Janeiro: FGV, 2007.

SANTOS, S. A. Educação: um pensamento negro contemporâneo. Jundiaí: Paco Editorial, 2014.

SILVA, F. J. R. Entrevista concedida ao Programa de História Oral do CPDOC. In: ALBERTI, V.; PEREIRA, A. (orgs.). Histórias do movimento negro no Brasil: depoimentos ao CPDOC. Rio de Janeiro: FGV, 2007.

SILVA, G. Ações afirmativas no Brasil e na África do Sul. Tempo Social, v. 18, p. 131-165, 2006

SILVA, J. A União dos Homens de Cor: aspectos do movimento negro dos anos 40 e 50. Estudos Afro-Asiáticos, v. 25, n. 2, p. 215-235, 2003.

SILVA Jr., H. Entrevista concedida ao Programa de História Oral do CPDOC. In: ALBERTI, V.; PEREIRA, A. (orgs.). Histórias do movimento negro no Brasil: depoimentos ao CPDOC. Rio de Janeiro: FGV, 2007.

SILVEIRA, O. Entrevista concedida ao Programa de História Oral do CPDOC. In: ALBERTI, V.; PEREIRA, A. (orgs.). Histórias do movimento negro no Brasil: depoimentos ao CPDOC. Rio de Janeiro: FGV, 2007.

SNOW, D.; BENFORD, R. Ideology, frame resonance, and participant mobilization. International Social Movement Research, v. 1, p. 197-217, 1988. 
SNOW, D.; BENFORD, R. Master frames and cycles of protest. In: MORRIS, A.; MUELLER, C. (eds.). Frontiers in Social Movement Theory. New Haven: Yale University Press, 1992.

SPENCER, M. The New Colored People: The mixed-race movement in America. New York: New York University Press, 1997.

SPICKARD, P. The illogical of American racial categories. In: ROOT, M. (Ed.). Racially Mixed People in America. Newbury Park: Sage, 1992.

SOUZA, E. Discurso proferido durante a audiência pública sobre a constitucionalidade de políticas de ação afirmativa de acesso ao ensino superior. (Notas Taquigráficas do Superior Tribunal Federal). Brasília, DF, 2010. Available on: <http://www.stf.jus.br/arquivo/cms/processoAudienciaPublicaAcaoAfirmativa/anexo/Notas_Taquigraficas_Audiencia_Publica.pdf $>$. Acessed on: 25 de junho de 2014.

SOUZA, J. Multiculturalismo, racismo e democracia: por que comparar Brasil e Estados Unidos. In: SOUZA, J. (org.). Multiculturalismo e Racismo: uma comparação Brasil - Estados Unidos. Brasília: Paralelo 15, 1997.

TARROW, S. The new transnational activism. New York: Cambridge University Press, 2006.

TELLES, E. As fundações norte-americanas e o debate racial no Brasil. Estudos Afro-Asiáticos, v. 24, n. 1, p.1 41-165, 2002.

THEODORO, M. Discurso proferido durante a audiência pública sobre a constitucionalidade de políticas de ação afirmativa de acesso ao ensino superior. (Notas Taquigráficas do Superior Tribunal Federal). Brasília, DF, 2010. Available on: <http://www.stf.jus.br/arquivo/ $\mathrm{cms} /$ processoAudienciaPublicaAcaoAfirmativa/anexo/Notas_Taquigraficas_Audiencia_Publica.pdf $>$. Acessed on: 25 de junho de 2014.

VICENTE, J. Discurso proferido durante a audiência pública sobre a constitucionalidade de políticas de ação afirmativa de acesso ao ensino superior. (Notas Taquigráficas do Superior Tribunal Federal). Brasília, DF, 2010. Available on: <http://www.stf.jus.br/arquivo/cms/processoAudienciaPublicaAcaoAfirmativa/anexo/Notas_Taquigraficas_Audiencia_Publica.pdf $>$. Acessed on: 25 de junho de 2014.

WILLIAMS, R. The cultural contexts of collective action: Constraints, opportunities, and the symbolic life of social movements. In: SNOW, D; SOULE, S.; KRIESI, H. (eds.) The Blackwell companion to social movements. Oxford: Blackwell, 2006.

ZALD, M.; ASH, R. Social Movement Organization: growth, decay and change. Social Forces, v. 44, p. 327-341, 1966.

Data de submissão: 01/10/2017.

Data de aprovação: 24/07/2018.

Creative Commons Atribuição 4.0 Internacional

Note: you can find this paper in Portuguese at http://www.revistaoes.ufba.br. 